\title{
Anxiety and self-esteem as mediators of the relation between family communication and indecisiveness in adolescence
}

\author{
Valentina Lo Cascio • Giovanni Guzzo • \\ Francesco Pace • Ugo Pace
}

Received: 9 October 2012/Accepted: 15 June 2013/Published online: 28 June 2013

(C) Springer Science+Business Media Dordrecht 2013

\begin{abstract}
In this study, we explored the unique and common contributions of anxiety, self-esteem, and family communication on indecisiveness among adolescents. Three hundred and fifty pupils from 13 to 16 years of age completed selfreport measures on indecisiveness, quality of family communication, trait anxiety, and self-esteem. The findings in this study showed that students' indecisiveness is predicted by family communication mediated by anxiety and self-esteem. These results have important implications for practice as it stresses the importance of anxiety and self-esteem. Nevertheless, the counselors could also focus on enhancing relationship-building skills by introducing the adolescents' career formation as an adolescent-parent joint project.
\end{abstract}

Résumé. L'anxiété et l'estime de soi comme médiateurs de la relation entre communication au sein de la famille et indécision chronique à l'adolescence. Dans cette étude, nous avons exploré les contributions uniques et communes de l'anxiété, de l'estime de soi et de la communication au sein de la famille sur l'indécision chronique auprès d'adolescents. Trois cent cinquante élèves âgés de 13 à 16 ans ont rempli des mesures d'auto-évaluation de l'indécision chronique, de la qualité de la communication familiale, de l'anxiété-trait et de l'estime de soi. Les résultats de cette étude ont montré que l'indécision des étudiants est expliquée par la communication au sein de la famille et que ce lien est médiatisé par l'anxiété et l'estime de soi. Ces résultats ont des implications importantes pour la pratique car

\footnotetext{
V. Lo Cascio $(\bowtie)$

Department of Economics, Business and Statistics, University of Palermo, 90100 Palermo, IT, Italy e-mail: valentina.locascio@unipa.it

G. Guzzo · U. Pace

Department of Human and Social Science, University of Enna “Kore”, Enna, Italy

F. Pace

Department of Psychology, University of Palermo, Palermo, Italy
} 
ils soulignent l'importance de l'anxiété et l'estime de soi. Néanmoins, les conseillers pourraient également se concentrer sur l'amélioration des compétences de construction relationnelle en introduisant la formation professionnelle des adolescents comme un projet conjoint adolescent-parent.

\section{Zusammenfassung. Angst und Selbstwertgefühl als Mediatoren der Bezie-} hung zwischen Kommunikation in der Familie und Unentschlossenheit in der Adoleszenz. In dieser Studie untersuchten wir die spezifischen und gemeinsamen Beiträge von Angst, Selbstwertgefühl und Kommunikation in der Familie auf Unentschlossenheit unter Jugendlichen. Dreihundertfünfzig Schüler, zwischen 13 bis 16 Jahre alt, füllten Skalen zur Unentschlossenheit, Qualität der Kommunikation in der Familie, Ängstlichkeit und Selbstwertgefühl aus. Die Ergebnisse dieser Studie zeigten, dass Unentschlossenheit der Schüler von Kommunikation in der Familie vorhergesagt wird, vermittelt durch Angst und Selbstwertgefühl. Diese Ergebnisse haben wichtige Implikationen für die Praxis, da sie die Bedeutung von Angst und Selbstwertgefühl hervorheben. Dennoch könnten sich die Beratungspersonen durch die Einführung der beruflichen Bildung der Jugendlichen als ein gemeinsames Projekt von Jugendliche-Elternteil auch auf die Verbesserung der Fähigkeiten zum Aufbau von Beziehungen konzentrieren.

\section{Resumen. Ansiedad y Autoestima como Mediadores de la Relación entre} Comunicación Familiar e Indecisión en la Adolescencia. En este estudio, exploramos las contribuciones únicas y comunes de la ansiedad, la autoestima y la comunicación de familia en la indecisión de los adolescentes. Tres y cientos cincuenta alumnos entre los 13 y 16 años completaron auto-evaluaciones sobre la indecisión, la calidad de comunicación familiar, los rasgos de ansiedad y la autoestima. Los resultados en este estudio muestran que la indecisión en los estudiantes es prevista por la comunicación familiar mediada por la ansiedad y la autoestima. Estos resultados tiene importantes implicaciones para la practica ya que destacan la importancia de la ansiedad y la autoestima. Sin embargo, los consejeros podrían también focalizarse en el aumento de sus habilidades para construir relaciones mediante la introducción de la formación profesional para adolescentes como un proyecto conjunto del adolescente-padre.

Keywords Family communication · Indecisiveness · Anxiety

Deciding is one of the most important activities in our lives because we have to make decisions constantly. Some people have more difficulties with decisionmaking than others; therefore, it seems plausible that there are individual differences in the extent to which we experience such difficulties with making decision (Rassin, 2007). There has long been interest on the part of the counselors in understanding the dynamics of undecided students. In particular, many studies have focused specifically on the differences between indecision and indecisiveness (Di Fabio, Palazzeschi, Asulin-Peretz, \& Gati, 2012; Santos, 2001). Indecision is 
generally regarded as a normal stage through which almost everyone passes during their lifetime; it involves a specific domain or situation, such as career indecision, and it does not necessarily imply that one has problems making decisions in other situations (Germeijs \& Verschueren, 2007). The second category, indecisiveness, is designated chronic or generalized indecision, reflected not only in one area but in other areas of life (Saka, Gati, \& Kelly, 2008).

In the large body of literature on indecisiveness, one major problem has been establishing indecisiveness as a separate construct from indecision. However, some researchers have recently demonstrated that indecisiveness is distinct from other forms of indecision (e.g., Germeijs \& De Boeck, 2002). Specifically, indecisiveness can be defined as a trait (Rassin, 2007) characterized by a chronic problem with making decisions across situations and domains (Germeijs \& De Boeck, 2002; Patalano \& Wengrovitz, 2006). Research findings have shown that indecisiveness has a significant negative impact on individuals' behavior during the process of making specific decisions. For example, individuals with high indecisiveness take more time to choose among alternatives, are more threatened by ambiguous situations, use less-exhaustive decision strategies, and require greater cognitive effort to make decisions (Rassin \& Muris, 2005a). In addition, they start to doubt whether their decision was the best possible one and tend to avoid decision-making because of their general reluctance to do so (Rassin \& Muris, 2005b). Furthermore, indecisiveness predicts difficulties in choosing a college major or a career (Germeijs, Verschueren, \& Soenens, 2006).

According to Germeijs and De Boeck (2002), indecisiveness is a multidimensional construct encompassing a variety of features. The descriptors for difficulty in making decisions are: (a) deciding takes a long time, (b) a tendency to delay making decisions, (c) a tendency to avoid making decisions, (d) leaving decisions to someone else, (e) instability of a decision, (f) worrying about decisions that are made, (g) regretting decisions that are made. Further, they stated that "indecisiveness does not refer to any specific kind of decision but to all kinds of decisions" (pp. 114-115).

\section{Family characteristics and indecisiveness}

A line of current research focuses on the family role in the development of indecisiveness among adolescents. Even as adolescents become increasingly peer oriented and aware of their peers' evaluations, parents continue to play a significant role in their children's development (e.g., Guzzo, Lo Cascio, \& Pace, 2013; Pace \& Zappulla, 2009; Schimmenti, 2012). In particular, some research has shown that family processes are an important area of inquiry in adolescent decision-making, and in particular that the quality of interpersonal relationships in a family can positively and negatively influence adolescents' decision-making processes (Nota, Ferrari, Solberg, \& Soresi, 2007). Moreover, Ferrari and Olivette (1993) found that certain child-rearing practices can account for some of the observed variance in indecisiveness, perhaps via their influences on more proximal contributors, such as anxiety. Furthermore, some studies have investigated the relation between family 
communication and adolescents' decision-making but they have yielded inconsistent results. For example, in a study involving 413 Dutch adolescents age 13-15, Jackson, Bijstra, Oostra, and Bosma (1998) found a weak relationship between family communication and decision-making. So, further empirical research into this relationship is needed.

Family communication can be defined as the "act of making information, ideas, thoughts, and feelings known among members of a family unit; it can be considered a critical aspect of healthy family relationships" (Olson \& Barnes, 2004, p. 1). The prominence of communication in theoretical constructions of family interactions attests to the high importance attributed to it. Olson (2011) has developed a theoretical model of marital and family systems known as the circumplex model which holds that well-functioning families are considered balanced, falling midrange in terms of cohesion and flexibility. In this model, family cohesion is defined as the emotional bonding that family members have towards one another. Family flexibility refers to the quality and application of the family's leadership, organization, roles, and relationship rules. Family communication is defined in terms of relatively concrete behaviors which are open to observation and description, such as discussion, open expressions of affection, nagging, and readiness to listen (Barnes \& Olson, 1985). In particular, the quality of family communication is high when family members are good listeners, can communicate clear messages to each other, support and empathize with to each other; its quality is low if closure, false messages, and avoidance characterize the communication among family members. Communication is a crucial component of the circumplex model. The authors hypothesized that effective communication facilitates movement toward and maintenance of systems at the desired (balanced) level of flexibility and cohesion. So, when communication is effective, a family is closer, more loving and more flexible in solving family problems.

Despite the empirical evidence demonstrating the important consequences of quality of family communication on adolescents, research into the nature of family communication presents challenging difficulties. One of the main difficulties is the complexity of family communication, presenting a wide variety of aspects on which researchers might focus. Most of the studies have concentrated on attitudinal and behavioral outcomes and concluded that better communication is associated with more positive outcomes for adolescents (Olson \& Barnes, 2004). Little attention, though, has been directed at examining family communication's influence on individual development. Huang (1999) has shown that individuals from conversation-oriented families exhibit greater desire for control, self-esteem, and sociability, whereas those from conformity-oriented families are more likely to be selfmonitoring and shy and to have lower self-esteem. In addition, family interactions appear to influence a child's ability to cope with a variety of situations (see McCartney \& Phillips, 2006, for a review). The results of these studies support and complement the ideas advanced by others about the benefits of effective family communication for adolescents.

In conclusion, communication within the family appears to be particularly important during adolescence because it could effectively support them during a stressful period of development. In fact, adolescents will be less likely to feel lonely 
in the external world when they are encouraged and supported and can always count on someone at home (Marta, 1997).

\section{Relationships between indecisiveness, anxiety, and self-esteem}

Research has indicated that individual differences play a role in the extent to which decisions are experienced as discomforting. Over the years, the literature has discussed the relationship between indecisiveness and various personality characteristics. From time to time, indecision has been related to perfectionism, behavioral procrastination, self-consciousness, decision-making self-efficacy, obsessive-compulsive tendencies, neuroticism, extraversion, and conscientiousness (Bacanli, 2006; Germeijs \& Verschueren, 2011; Rassin \& Muris, 2005b). Despite this lengthy list of associations, these findings are not completely consistent.

In particular, the relationship between indecisiveness and anxiety has received theoretical and empirical attention. Trait anxiety is a relatively stable personality trait which refers to individual differences in the frequency and intensity with which anxiety manifests. It consists of feelings of apprehension, tension, and increased activity of the autonomic nervous system (Spielberger, Gorsuch, Lushene, Vagg, \& Jacobs, 1983). Some research has found positive correlations between indecisiveness and trait anxiety (e.g., Germeijs \& Verschueren, 2011). For instance, in a sample of 345 students in Portuguese secondary schools, Santos (2001) demonstrated that trait anxiety is the most important variable in the prediction of indecisiveness.

Indecisiveness also seems to be positively associated with a poorly defined sense of identity and low self-esteem (e.g., Bacanli, 2006). Generally, self-esteem is described as a personal evaluation that an individual makes of her or himself, their sense of their own worth, value, importance, or capabilities. In particular, it is a component of self-concept, a global, positive or negative attitude toward oneself (Rosenberg, 1965). Thus, the relationship between indecisiveness and self-esteem has been extensively investigated. For instance, in a sample of 125 college undergraduates, Patalano and LeClair (2011) showed a strong negative relation between indecisiveness and self-esteem. Moreover, Germeijs and De Boeck (2002) found that low self-esteem is associated more with indecisiveness than with career indecision.

\section{Aims of the study}

The main aim of the present study was to explore the unique and common contributions of quality of family communication, self-esteem, and anxiety trait on indecisiveness among Italian adolescents. Regarding the unique contributions of quality of family communication, anxiety, and self-esteem on indecisiveness, we hypothesized that both quality of family communication and self-esteem would be positively correlated with adolescents' decisiveness, whereas the anxiety trait would be negatively correlated with adolescents' decisiveness. Regarding the common 
contributions of quality of family communication, anxiety, and self-esteem on indecisiveness, we hypothesized that anxiety and self-esteem would mediate the relationship between quality of family communication and indecisiveness.

\section{Method}

\section{Participants}

Participants in the study were 350 pupils (201 boys and 149 girls) from 13 to 16 years of age $(M=14.90 ; S D=.93)$, attending five public high schools located in different cities of South Italy. In terms of type of high school, $24 \%$ of students were enrolled in science-humanities focused schools, $33 \%$ were in technical-industrial arts schools, and $43 \%$ were in vocational schools. All the participants were Italian. To recruit participants, we employed a 'passive' consent procedure (i.e., informing the parents in advance about the nature of the study and providing the opportunity for the parents to call our research office if they did not want their child participating in the study). We sent letters to the parents of the students in the target classes informing them of the nature of the study. We provided an opportunity to contact the child's school or our office about the project. There were no parents that objected to involvement of their child in the study. We obtained the assent from all the adolescents involved in the study. From a total sample of 360 respondents, the majority provided useable data; only ten questionnaires were rejected due to many missing answers.

\section{Measures}

\section{Indecisiveness}

Indecisiveness scale (Germeijs \& De Boeck, 2002; Italian version, Lo Presti \& Drammis, 2012) consists of 22 items which investigate the following characteristics: difficulty, don't know how, feeling uncertain, takes a long time, delaying, avoidance, leaving to others, reconsideration, worrying, regretting, and calling oneself indecisive. For each feature, it consists of positively and negatively formulated item, to counteract response tendencies, so that the total number of items was 22 . Each item of this scale (e.g. "It is hard for me to come to a decision") was formulated as a statement for which the subjects had to indicate the extent of agreement on a 7 -point scale going from (0) strongly disagree to (6) strongly agree. The items were recoded so that higher scores reflect higher levels of decisiveness. The internal consistency reliability of the scale is .92 and the mean score for indecisiveness is 2.58 ( $S D=.86$ ) based on a sample of 748 adolescents (Germeijs et al., 2006). In the current study, the internal consistency (Cronbach's $\alpha$ ) of the scale is .83 .

\section{Family communication}

The family communication scale (FCS; Olson, 2011; Italian version, Baiocco, Cacioppo, Laghi, \& Tafà, 2012) is a self-report measure of quality of family 
communication and it is a shorter 10-item scale based on the longer 20-item parentadolescent communication scale (Barnes \& Olson, 1985). For each item, participants are asked to rate how much they agree with the statement on a 5-point Likert scale ranging from 1 (strongly disagree) to 5 (strongly agree). It provides information concerning the adolescent's view of the nature of the concrete interactions between him/herself and other family members. An example of question is "Family members are very good listeners". Family communication can range from poor (family members have many concerns about the quality of their family communication) to very effective (family members feel very positive about the quality and quantity of their family communication). Higher scores reflect a perception of very effective family communication. The internal consistency reliability of the scale is .90 ; the test-retest is .86; the mean score for family communication is 36.20 ( $S D=9.00$ ) based on a sample of 2,465 individuals (Olson $\&$ Gorall, 2006). In the current study, the internal consistency reliability of the scale is .84 .

\section{State-trait anxiety}

State-Trait Anxiety Inventory form Y (Spielberger et al., 1983; Italian version, Pedrabissi \& Santinello, 1989) is a widely used questionnaire developed to measure self-reported trait anxiety (TRAIT-A) and state anxiety (STATE-A), and it is suitable for people with an elementary cultural level, young people, adults and older adults. Both scales contain 20 items; in this study we have used only trait anxiety scale. The trait anxiety items are rated on a 4-point frequency scale (from 1 "almost never" to 4 "almost always"); the range of scores is $20-80$. In this scale the respondent is asked to indicate "how [he/she] generally feels" with respect to different items like: "I feel nervous and restless" or "I wish I could be as happy as others seem to be". Higher scores reflect higher levels of trait anxiety. The normative values are available for high school students with a mean score of $39.45(S D=9.74)$ for boys and $40.54(S D=12.86)$ for girls. The Italian version of the scale has proved to be reliable: Cronbach's alpha and test-retest reliability coefficients were .85 and .82 , respectively. In the current study, the internal consistency (Cronbach's $\alpha$ ) of the scale is .87 .

\section{Self-esteem}

Rosenberg Self-Esteem Scale (Rosenberg, 1965; Italian version, Prezza, Trombaccia, \& Armento, 1997), is a 10-item questionnaire (five with a positive orientation and five with a negative orientation) referring to feelings and attitudes regarding oneself. Participants were asked to rate, on a modify 7-point Likert scale (from 1 "strongly disagree" to 7 "strongly agree"), the extent of their agreement on each item. An example of question is "I feel that I have a number of good qualities". The items were recoded so that higher scores reflect higher levels of self-esteem. The mean score for self-esteem is $55.30(S D=10.10)$ based on a sample of 119 college students for ages 17-27 years (Roberts, Gotlib, \& Kassel, 1996). The Italian version of the scale has proved to be reliable: Cronbach's alpha and test-retest reliability 
coefficients were .84 and .76 , respectively. In the current study, the internal consistency reliability of the scale is .82 .

Procedure

Participants completed self-report measures on indecisiveness, family communication, trait anxiety, self-esteem, and provided also demographic information by means of a brief list of questions included in the self-report measures. This research complied with ethical rules of the Italian Psychological Association.

\section{Data analysis}

We conducted preliminary analyses, including descriptive statistics on the independent and dependent variables, and intercorrelations between all the variables. Then, we conducted a series of one-way analyses of variance to examine gender differences between students. Furthermore, we assessed multicollinearity of variables using the variance inflation factor (VIF), which is a measure of the amount of multicollinearity in a set of multiple regression variables; VIF values $>10$ indicate collinearity. To explore whether the family communication, anxiety, and self-esteem were associated with indecisiveness, hierarchical regression analysis were carried out using indecisiveness as the dependent variable, with family communication, anxiety trait, and self-esteem as the predictor variables. In the first step, we entered age into the regression analysis to serve as a control variable. In the second and third steps, we added family communication variable and anxiety and self-esteem variables. Moreover, to test the hypothesized mediational pathways of anxiety and self-esteem in the relation between family communication and indecisiveness, we used structural equation models. A confirmatory factor analysis (CFA) with maximum likelihood estimation was performed to examine the measurement model and verify that the measurement variables reflected the unobserved constructs or latent variables in a reliable manner. Then, the structural model was conducted on the covariance matrix using AMOS 18 with maximum likelihood estimation. We evaluated the fit of the model using the following fit indices: Chi square goodness-of-fit to degrees of freedom ratio $\left(\chi^{2} / d f\right)$, goodness-offit index (GFI), the adjusted GFI (AGFI), the comparative fit index (CFI), the standardized root mean square residual (SRMR), and the root mean square error of approximation (RMSEA). These indices are regarded as indicative of a good fit when Chi square goodness-of-fit to degrees of freedom ratio is smaller than 3, GFI is $>.90$, AGFI $>.80, \mathrm{CFI}>.95$, and SRMR and RMSEA values are smaller than .08 and .06 respectively (Hu \& Bentler, 1999).

\section{Results}

Descriptive analyses for all independent and dependent variables are presented in Table 1. In order to analyze possible gender differences between students in terms of the relevant variables being investigated, we used separate one-way analyses of 
variance. They revealed that girls showed lower scores in indecisiveness scale, $F(1.348)=9.03, p<.01, \eta^{2}=.04$, and in Self-Esteem scale, $F(1.348)=14.65$, $p<.01, \eta^{2}=.05$. Moreover, the girls showed higher scores in trait anxiety scale, $F(1.348)=23.23, p<.01, \eta^{2}=.06$. There were no differences in the scores of FCS, $F(1.348)=2.22, p>.05, \eta^{2}=.006$.

Table 2 presents the correlation matrix. All measures were significantly correlated in expected direction with indecisiveness. Data showed that Indecisiveness scale was positively related to Self-Esteem scale $(r=.53, p<.01)$ and FCS $(r=.26, p<.01)$. In addition, it was negatively related to Trait Anxiety scale $(r=-.56, p<.01)$. Since some independent variables presented moderately high correlations among themselves, we decided to assess the degree of multicollinearity of these. The analysis of the tolerance values and the VIFs did not detect problems of multicollinearity.

Results of the hierarchical regression analysis conducted to examine whether variables at each step made a unique contribution in explaining variance in indecisiveness, showed that the family communication, anxiety, and self-esteem gave a significant model for each of them explaining the variance (Table 3). In particular, age was entered into the regression analysis as a control variable and it was not a significant predictor. In the second step, Family Communication was positively associated with Indecisiveness scale, $\beta=.26, t=5.01, p<.0001$, accounted $6 \%$ of the total variance and it made a significant contribution, $\Delta R^{2}$ at step $2=.06, p<.001$. In the third step, Trait Anxiety was negatively associated with Indecisiveness scale, $\beta=-.37, t=-5.81, p<.001$, and self-esteem was positively associated with Indecisiveness scale, $\beta=.26, t=4.06, p<.001$. Both the variables accounted $28 \%$ of the total variance and they made further significant contributions, $\Delta R^{2}$ at step $3=.28, p<.001$. Interesting to note that in the third step, the family communication is not significant, leading to hypothesize mediational role of anxiety and self-esteem. The overall regression equation accounted for a significant $34 \%$ of the variance in indecisiveness scores, $F(4.346)=45.27$, $p<.001$.

Before testing the structural equations model, a CFA was conducted to examine the measurement model. For this measurement model latent constructs, indecisiveness, family communication, anxiety, and self-esteem were allowed to correlate. The

Table 1 Descriptive statistics for the total sample, for boys and girls

\begin{tabular}{|c|c|c|c|c|c|c|c|c|c|}
\hline \multirow[t]{2}{*}{ Scales } & \multicolumn{5}{|l|}{ Total } & \multicolumn{2}{|l|}{ Boys $^{a}$} & \multicolumn{2}{|l|}{ Girls $^{b}$} \\
\hline & $M$ & $S D$ & Skewness & Kurtosis & $\alpha$ & $M$ & $S D$ & $M$ & $S D$ \\
\hline Indecisiveness & 3.56 & 0.76 & -0.42 & 0.52 & 0.83 & 3.72 & 0.76 & 3.40 & 0.74 \\
\hline Self-esteem & 53.84 & 10.88 & -0.91 & 1.20 & 0.82 & 55.47 & 10.79 & 50.91 & 10.47 \\
\hline Trait anxiety & 41.00 & 10.11 & 0.70 & 0.56 & 0.87 & 39.12 & 9.61 & 44.39 & 10.14 \\
\hline Family communication & 37.23 & 7.23 & -0.81 & 0.64 & 0.84 & 36.80 & 6.97 & 38.00 & 7.66 \\
\hline
\end{tabular}

$N=350$

a $n=201$

b $n=149$ 
results of the CFA suggested a reasonable fit between the measurement model and the observed data, $\quad \chi^{2}(1635)=3188.36, \quad p<.001, \quad \chi^{2} / d f=1.95, \quad$ GFI $=.91$; $\mathrm{AGFI}=.83 ; \mathrm{CFI}=.92 ; \mathrm{SRMR}=.06 ; \mathrm{RMSEA}=.05$. The only exception for this model is the CFI value, which fell somewhat below the usual cutoff criterion. Although recent studies have shown that a value of CFI $\geq .95$ is presently recognized as indicative of good fit (Hu \& Bentler, 1999), some researches advanced that a cut-off criterion of CFI >.90 is an adequate value of fit (Byrne, 2001).

Next, structural equation analysis was performed to test the mediating role of anxiety and self-esteem as mediators of the relationship between family communication and indecisiveness. The results suggested a reasonable fit of the model to the data, $\chi^{2}(60)=153.85, \quad p<.001, \quad \chi^{2} / d f=2.56, \quad$ GFI $=.91 ; \quad$ AGFI $=.82 ;$ $\mathrm{CFI}=.93 ; \mathrm{SRMR}=.07$; RMSEA $=.06$ (Figure 1 ). Therefore, results of mediation analyses suggest that trait anxiety and self-esteem might play a crucial role in linking family communication and indecisiveness in adolescence.

\section{Discussion and conclusions}

The purpose of this study was to examine the relationship between indecisiveness, self-esteem, anxiety, and quality of family communication, focusing on the unique and common contributions of quality of family communication, self-esteem, and trait anxiety on indecisiveness. In fact, this was the fundamental question motivating the present research: Why is it that some people are more indecisive than others? Previous findings emphasized the role of individual characteristics on indecisiveness; nevertheless, earlier studies have not observed the role of family communication on indecisiveness.

Data from primary analyses showed that girls are significantly more indecisive than are boys. These results were confirmed by Rassin and Muris (2005b) in a study with 135 undergraduate Dutch students but are in contrast with other studies (Patalano \& Wengrovitz, 2006) which found no significant gender differences in indecisiveness. In addition, girls have significantly more trait anxiety and lower selfesteem than do boys. It can be speculated that the association of indecisiveness with trait anxiety and low self-esteem is due to a particular approach by girls toward adolescence developmental tasks; this speculation agrees with the finding by

Table 2 Correlations between age, indecisiveness, self-esteem, anxiety, and family communication

\begin{tabular}{lrrrr}
\hline & 1 & 2 & 3 & 4 \\
\hline 1. Age & & & & \\
2. Indecisiveness & 0.06 & & & \\
3. Self-esteem & 0.04 & $0.53^{* * *}$ & & \\
4. Trait anxiety & -0.05 & $-0.56^{* * *}$ & $-0.72^{* * *}$ & \\
5. Family communication & 0.03 & $0.26^{* * *}$ & $0.40^{* * *}$ & $-0.42^{* * *}$ \\
\hline
\end{tabular}

$N=350$

$* * * p<.001$ 
Table 3 Hierarchical regression predicting indecisiveness from age, family communication, anxiety, and self-esteem

\begin{tabular}{llllll}
\hline & Variables & $\beta$ & Adj $R^{2}$ & $F$ & $\Delta R^{2}$ \\
\hline Step 1 & Age & 0.06 & 0.001 & 1.30 & \\
Step 2 & Age & 0.05 & 0.06 & $13.25^{* * * *}$ & $0.06^{* * * *}$ \\
& Family communication & $0.26^{* * *}$ & & & \\
Step 3 & Age & 0.03 & 0.34 & $45.27^{* * *}$ & $0.28^{* * *}$ \\
& Family communication & 0.01 & & & \\
& Trait anxiety & $-0.37^{* * *}$ & & & \\
& Self-esteem & $0.26^{* * *}$ & & & \\
\hline
\end{tabular}

$N=350$

$* * * p<.001$

Vondracek, Hostetler, Schulenberg, and Shimizu (1990) that, among girls but not boys, the level of indecision could be linked to change-sensitivity regarding selfconcept. Similarly, Creed, Patton, and Bartrum (2004) have more recently shown that, again among girls but not boys, internal barriers, such as low level of selfesteem and self-efficacy, negatively predict decision-making.

Regarding the predictive role of family communication, self-esteem, and trait anxiety on indecisiveness, results showed that each of the predictors in this study significantly predicted indecisiveness. Of these, trait anxiety is the strongest

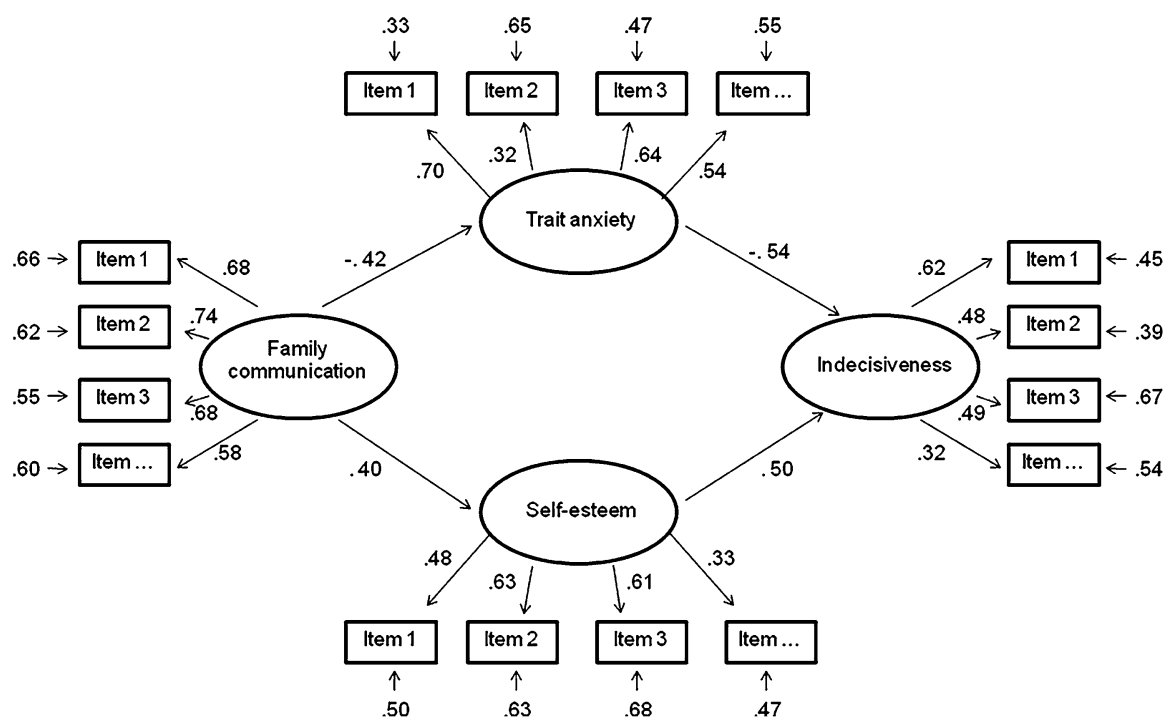

Fig. 1 Structural equation model for anxiety and self-esteem as mediators of the relation between family communication and indecisiveness. Standardized estimates are reported. Item... = item with the lowest standardized estimate of the remaining items of the latent variable. All structural coefficients are statistically significant at $p<.001$. The pathway between family communication and indecisiveness is not significant (standardized estimate $=.03, p=n s$ ) after controlling for self-esteem and anxiety 
statistical predictor. At the same time, the results showed moderately high correlation between the variables; that is, indecisiveness is significantly and positively related to trait anxiety and negatively related to self-esteem. There are several theoretical explanations for the link between trait anxiety and indecisiveness. According to Miu, Heilman, and Housern (2008), individuals with high trait anxiety are likely to experience anxiety in decision-making situations as well: one way to escape from the anxiety-provoking decisional situation or regulate the negative emotion is to avoid or put off making the decision as long as possible, a behavior characteristic of indecisiveness. Furthermore, the literature showed the link between self-esteem and indecisiveness. Some studies emphasized procrastination as a strategy to protect a vulnerable sense of self-esteem and an individual's self-evaluation (Bacanli, 2006).

In addition, the present study also allowed us to highlight the important role played by family functioning, especially communication, in prediction of indecisiveness. Through family communication, adolescents learn ways of interacting with others by being able to listen, to make their needs and wants known and to negotiate when conflicts emerge. Effective family communication allows adolescents to discuss decision options with parents, to act on the advice provided and to make decisions easily. When family communication is poor, however, adolescents are less likely to discuss options with their parents and to accept the advice offered and have difficulty making decisions. Thus, family has an important role in development of decision-making. This result is in accord with clinical observations as well as empirical studies (e.g., Rosario et al., 2009) that provided evidence for the role of parental influence in development of an important aspect of indecisiveness: procrastination.

Finally, with regard to the results concerning the joint contribution of family communication, trait anxiety, and self-esteem, data evidenced that both trait anxiety and self-esteem act as total mediators of the relation between family communication and indecisiveness. Previous research established an indirect relation between parenting and procrastination, mediated through individual characteristics such as self-system (e.g., Pychyl, Coplan, \& Reid, 2002). Our results are in line with these researches and show that while family communication is an important predictor of indecisiveness, it plays a role in indecisiveness through anxiety and self-esteem. There is a great deal of empirical evidence to suggest that parenting variables have a significant effect on children's development (e.g., Guzzo, Lo Cascio, Pace, \& Zappulla, 2013; Nakao et al., 2000). This study found that adolescents with effective family communication are likely to have positive feelings of self-esteem and to experience less anxiety, characteristics associated with indecisiveness (Bacanli, 2006; Germeijs \& Verschueren, 2011). It follows that family communication influences the development of key factors closely related to indecisiveness. Therefore, parents could help prevent indecisiveness in their children by promoting the development of personal characteristics that support competence in decision-making. Overall, this study extends the literature by focusing on the importance of family communication, anxiety, and self-esteem in the development of indecisiveness.

Some limitations of the present research are noteworthy, all of which suggest rewarding avenues for further research. First, this research is based on adolescents' 
self-reports. This methodological approach has been widely used by previous researchers, but self-report inventories are likely to be influenced by the participants' need for social desirability. Second, the sample was of only moderate size and relatively homogeneous. It would be interesting to see if our results can be reproduced in other countries. Finally, we collected all the data at a single point in time to focus specifically on the issues of the co-occurrence; it would be more correct to underscore the relationships among variables rather than their predictive roles. Future longitudinal research should investigate the development of the variables explored in the present study.

These results have important implications for practice as they indicate that interventions aiming at increasing self-esteem or lower anxiety might have also a positive impact on indecisiveness. Moreover, the findings of this study have shown that students' indecisiveness is also predicted by family characteristics, relationship that is mediated by anxiety and self-esteem. Therefore, being more aware of the many and complex variables involved in development of indecisiveness should open the door to more targeted and outcome-oriented counseling strategies. Indeed, the counselors cannot approach each individual with a predetermined plan to assist them with decision making process but they should give to the students a personalized approach that accounts for their specific personal characteristics, such as anxiety and self-esteem.

Nevertheless, the counselors should explore the level and valence of parental communication in adolescents. Assessing parental communication may shed light on students' difficulties in making decision in general and in regard to career in particular, encountered when adolescents perceive their parents as weakly communicating. These results help design appropriate counseling interventions. However, counselor intervention based only on treatment of the single variables, family communication, anxiety, or indecisiveness, would not act on the core problem, which is that starting from a dysfunctional family communication would establish in adolescents, via anxiety and low self-esteem, the chronic problem with making decisions across situations. According to Young et al. (2006), the counselors could focus, on the contrary, on enhancing relationship-building skills by introducing the adolescents' career formation as an adolescent-parent joint project.

Acknowledgments The authors would like to thank Vincenza Blunda, Mario Noto, Elena Scrima, and Marisa Ribaudo for their help in the collection and loading of data. We also wish to thank all of the instructors and students who participated in this study.

\section{References}

Bacanli, F. (2006). Personality characteristics as predictors of personal indecisiveness. Journal of Career Development, 32, 320-332. doi:10.1177/0894845305282941.

Baiocco, R., Cacioppo, M., Laghi, F., \& Tafà, M. (2012). Factorial and construct validity of FACES IV among Italian adolescents. Journal of Child and Family Studies. doi:10.1007/s10826-012-9658-1.

Barnes, H., \& Olson, D. (1985). Parent adolescent communication and the circumplex model. Child Development, 56, 438-447. doi:10.2307/1129732.

Byrne, B. M. (2001). Structural equation modeling with AMOS: Basic concepts, applications, and programming (pp. 79-88). Mahwah, NJ: Lawrence Erlbaum Associates, Inc. 
Creed, P. A., Patton, W., \& Bartrum, D. (2004). Internal and external barriers, cognitive style, and the career development variables of focus and indecision. Journal of Career Development, 30, 277-294. doi:10.1023/B:JOCD.0000025116.17855.ea.

Di Fabio, A., Palazzeschi, L., Asulin-Peretz, L., \& Gati, I. (2012). Career indecision versus indecisiveness: Associations with personality traits and emotional intelligence. Journal of Career Assessment, 21, 42-56. doi:10.1177/1069072712454698.

Ferrari, J. R., \& Olivette, M. J. (1993). Perceptions of parental control and the development of indecision among late adolescent females. Adolescence, 28(112), 963-970.

Germeijs, V., \& De Boeck, P. (2002). A measurement scale for indecisiveness and its relationship to career indecision and other types of indecision. European Journal of Psychological Assessment, 18, 113-122. doi:10.1027//1015-5759.18.2.113.

Germeijs, V., \& Verschueren, K. (2007). Educational choices in adolescence: The decision-making process, antecedents, and consequences. In V. B. Skorikov \& W. Patton (Eds.), Career development in childhood and adolescence (pp. 203-219). Rotterdam, The Netherlands: Sense.

Germeijs, V., \& Verschueren, K. (2011). Indecisiveness and big five personality factors: Relationship and specificity. Personality and Individual Differences, 50, 1023-1028. doi:10.1016/j.paid.2011.01.017.

Germeijs, V., Verschueren, K., \& Soenens, B. (2006). Indecisiveness and high school students' career decision-making process: Longitudinal associations and the mediational role of anxiety. Journal of Counseling Psychology, 53, 397-410. doi:10.1037/0022-0167.53.4.397.

Guzzo, G., Lo Cascio, V., \& Pace, U. (2013). The role of individual and relational characteristics on alcohol consumption among Italian adolescents: A discriminant function analysis. Child Indicators Research. doi:10.1007/s12187-013-9188-4.

Guzzo, G., Lo Cascio, V., Pace, U., \& Zappulla, C. (2013). Psychometric properties and convergent validity of the dependency-oriented and achievement-oriented psychological control scale (DAPCS) with Italian adolescents. Journal of Child and Family Studies. doi:10.1007/s10826-013-9786-2.

Hu, L. T., \& Bentler, P. M. (1999). Cutoff criteria for fit indexes in covariance structure analysis: Conventional criteria versus new alternatives. Structural Equation Modeling: A Multidisciplinary Journal, 6, 1-55. doi:10.1080/10705519909540118.

Huang, L. N. (1999). Family communication patterns and personality characteristics. Communication Quarterly, 47, 230-243. doi:10.1080/01463379909370136.

Jackson, S., Bijstra, J., Oostra, L., \& Bosma, H. (1998). Adolescents' perceptions of communication with parents relative to specific aspects of relationships with parents and personal development. Journal of Adolescence, 21, 305-322. doi:10.1006/jado.1998.0155.

Lo Presti, A., \& Drammis, L. M. (2012). Un contributo alla validazione italiana del Career Factors Inventory [A contribution to the Italian validation of the Career Factors Inventory]. CounselingGiornale Italiano di Ricerca e Applicazioni, 2, 217-231.

Marta, E. (1997). Parent-adolescent interactions and psychosocial risk in adolescents: An analysis of communication support and gender. Journal of Adolescence, 20, 473-487. doi:10.1006/ jado.1997.0103.

McCartney, K., \& Phillips, D. (Eds.). (2006). The handbook of early childhood development. Oxford, UK: Blackwell Publishing.

Miu, A. C., Heilman, R. M., \& Houser, D. (2008). Anxiety impairs decision-making: Psychophysiological evidence from an Iowa Gambling Task. Biological Psychology, 77, 353-358. doi:10.1016/ j.biopsycho.2007.11.010.

Nakao, K., Takaishi, J., Tatsuta, K., Katayama, H., Iwase, M., Yorifuji, K., et al. (2000). The influences of family environment on personality traits. Psychiatry and Clinical Neurosciences, 54, 91-95. doi: 10.1046/j.1440-1819.2000.00642.x.

Nota, L., Ferrari, L., Solberg, V. S. H., \& Soresi, S. (2007). Career search self-efficacy, family support, and career indecision with Italian youth. Journal of Career Assessment, 15, 181-193. doi: $10.1177 / 1069072706298019$.

Olson, D. H. (2011). FACES IV and the circumplex model: Validation study. Journal of Marital and Family Therapy, 3, 64-80. doi:10.1111/j.1752-0606.2009.00175.x.

Olson, D. H., \& Barnes, H. L. (2004). Family communication. In D. H. Olson, D. M. Gorall, \& J. Tiesel (Eds.), FACES IV package. Minneapolis, MN: LifeInnovations, Inc.

Olson, D. H., \& Gorall, D. M. (2006). Faces IV and the circumplex model. Minneapolis, MN: Life Innovations. 
Pace, U., \& Zappulla, C. (2009). Identity processes and quality of emotional autonomy: The contribution of two developmental tasks on middle-adolescents' subjective well-being. Identity: An International Journal of Theory and Research, 9, 323-340. doi:10.1080/15283480903422798.

Patalano, A. L., \& LeClair, Z. (2011). The influence of group decision making on indecisiveness-related decisional confidence. Judgment and Decision Making, 6(2), 163-175.

Patalano, A. L., \& Wengrovitz, S. M. (2006). Cross-cultural exploration of the indecisiveness scale: A comparison of Chinese and American men and women. Personality and Individual Differences, 41, 813-824. doi:10.1016/j.paid.2006.03.023.

Pedrabissi, L., \& Santinello, M. (1989). Nuova versione italiana dello S.T.A.I.forma Y [New Italian version of the S.T.A.I. form Y]. Firenze, IT: Organizzazioni Speciali.

Prezza, M., Trombaccia, F. R., \& Armento, L. (1997). La scala dell'autostima di Rosenberg. Traduzione e validazione italiana [The Rosenberg Self-Esteem Scale: Italian translation and validation]. Bollettino di Psicologia Applicata, 223, 35-44.

Pychyl, T. A., Coplan, R. J., \& Reid, P. A. M. (2002). Parenting and procrastination: Gender differences in the relations between procrastination, parenting style and self-worth in early adolescence. Personality and Individual Differences, 33, 271-285. doi:10.1016/S0191-8869(01)99151-9.

Rassin, E. (2007). A psychological theory of indecisiveness. Netherlands Journal of Psychology, 63, 1-11. doi:10.1007/BF03061056.

Rassin, E., \& Muris, P. (2005a). Indecisiveness and the interpretation of ambiguous situations. Personality and Individual Differences, 39, 1285-1291. doi:10.1016/j.paid.2005.06.006.

Rassin, E., \& Muris, P. (2005b). To be or not to be ... indecisive: Gender differences, correlations with obsessive-compulsive complaints, and behavioral manifestation. Personality and Individual Differences, 38, 1175-1181. doi:10.1016/j.paid.2004.07.014.

Roberts, J. E., Gotlib, I. H., \& Kassel, J. D. (1996). Adult attachment security and symptoms of depression: The mediating roles of dysfunctional attitudes and low self-esteem. Journal of Personality and Social Psychology, 70, 310-320. doi:10.1037/0022-3514.70.2.310.

Rosario, P., Costa, M., Núñez, J. C., González-Pienda, J., Solano, P., \& Valle, A. (2009). Academic procrastination: Associations with personal, school, and family variables. The Spanish Journal of Psychology, 12, 118-127. doi:10.1017/S11387416-00001530.

Rosenberg, M. (1965). Society and the adolescent self-image. Princeton, NJ: Princeton University Press.

Saka, N., Gati, I., \& Kelly, K. R. (2008). Emotional and personality-related aspects of career decisionmaking difficulties. Journal of Career Assessment, 16, 403-424. doi:10.1177/1069072708318900.

Santos, P. J. (2001). Predictors of generalized indecision among Portuguese secondary school students. Journal of Career Assessment, 9, 381-396. doi:10.1177/106907270100900405.

Schimmenti, A. (2012). Unveiling the hidden self: Developmental trauma and pathological shame. Psychodynamic Practice, 18, 195-211. doi:10.1080/14753634.2012.664873.

Spielberger, C. D., Gorsuch, R. L., Lushene, R., Vagg, P. R., \& Jacobs, G. A. (1983). Manual for the State-Trait Anxiety Inventory. Palo Alto, CA: Consulting Psychologists Press.

Vondracek, F. W., Hostetler, M., Schulenberg, J. E., \& Shimizu, K. (1990). Dimensions of career indecision. Journal of Counseling Psychology, 37, 98-106. doi:10.1037/0022-0167.37.1.98.

Young, R. A., Marshall, S., Domene, J. F., Arato-Bolivar, J., Hayoun, R., Marshall, E., ... Valach, L. (2006). Relationships, communication, and career in the parent-adolescent projects of families with and without challenges. Journal of Vocational Behavior, 68, 1-23. doi:10.1016/j.jvb.2005.05.001. 